\title{
Evaluation of the renovation of a Danish single-family house based on measurements
}

\author{
Grøn Bjørneboe, Matilde; Svendsen, Svend ; Heller, Alfred
}

Published in:

Energy and Buildings

Link to article, DOI:

10.1016/j.enbuild.2017.04.050

Publication date:

2017

Document Version

Peer reviewed version

Link back to DTU Orbit

Citation (APA):

Grøn Bjørneboe, M., Svendsen, S., \& Heller, A. (2017). Evaluation of the renovation of a Danish single-family house based on measurements. Energy and Buildings, 150. https://doi.org/10.1016/j.enbuild.2017.04.050

\section{General rights}

Copyright and moral rights for the publications made accessible in the public portal are retained by the authors and/or other copyright owners and it is a condition of accessing publications that users recognise and abide by the legal requirements associated with these rights.

- Users may download and print one copy of any publication from the public portal for the purpose of private study or research.

- You may not further distribute the material or use it for any profit-making activity or commercial gain

- You may freely distribute the URL identifying the publication in the public portal

If you believe that this document breaches copyright please contact us providing details, and we will remove access to the work immediately and investigate your claim 


\title{
Evaluation of the renovation of a Danish single-family house based on measurements
}

Corresponding author:

Matilde Grøn Bjørneboe; Department of Civil Engineering, Technical University of Denmark, Brovej Building 118, DK-2800 Kgs. Lyngby, DENMARK, matg@byg.dtu.dk

Co-authors:

Svend Svendsen; Department of Civil Engineering, Technical University of Denmark, Brovej Building 118, DK-2800 Kgs. Lyngby, DENMARK, ss@byg.dtu.dk

Alfred Heller; Department of Civil Engineering, Technical University of Denmark, Brovej Building 118, DK-2800 Kgs. Lyngby, DENMARK, alfh@byg.dtu.dk

\begin{abstract}
Building renovation is too often carried out with only one objective: necessary maintenance, updating design and functions, or reducing energy consumption. But, if a necessary maintenance is exploited as an opportunity for renovation, energy improvements can be implemented, house functions can be updated, and indoor climate improved with minimal nuisance and expense. This paper illustrates this approach by documenting the renovation of a single-family house in Denmark, and monitoring its energy consumption and indoor climate before and after the renovation. Building elements were replaced where necessary, and the total energy consumption was reduced by $23 \%$, giving the house owners a saving of about DKK 8400 per year. The energy consumption for heating was reduced by $53 \%$, close to the $58 \%$ found using dynamic simulations. The temperatures reached a more comfortable level, and the house owners were satisfied with the result. The increased value of the house was estimated to cover about $77 \%$ of the investment.
\end{abstract}

\section{Keywords}

Measurement and verification, simulation, energy renovation, detached single-family house

\section{Highlights}

- A Danish single-family house renovated for durability, functions and energy

- Simulation of the house before and after renovation

- Measurement of energy and indoor climate for a year before and after

- $53 \%$ reduction in heating consumption with better indoor climate

- Mortgage bank estimates increase in house value corresponds to $77 \%$ of the investment. 


\section{Introduction}

The energy renovation of existing building stock is one way to reduce the overall use of fossil fuels and achieve a society based on sustainable energy. The large potential for savings through the renovation of the many single-family houses built in Denmark in the period 1960-1980 has been pointed out by many researchers (Gram-Hanssen 2014; Tommerup and Svendsen 2006; Vanhoutteghem et al. 2009). But while this potential for savings has been supported by simulations and surveys, actual case studies based on measurements are rare. An international literature review by $\mathrm{Ma}$ et al. (2012) concludes that while measurement and verification are effective ways of documenting energy savings achieved as a result of renovation, most studies have been based on simulations. There is still a need for more research with practical cases, because the actual savings achieved through energy renovations might not be the same as those found in simulations (EBC 2012). This difference, often called the performance gap, is likely due to deviation between simulations and the real world, including changes in user behaviour known as the rebound effect (Audenaert et al. 2011; Galvin and Sunikka-Blank 2013; Majcen et al. 2013). Harrestrup and Svendsen (2015) describe the renovation of a Danish multi-storey building with heritage value, where they estimated the resulting energy savings using measurements and compared them with simulations made using the program IDA ICE. Here the total measured saving was $47 \%$, while the calculations had shown a theoretical saving of 39-61\% depending on room set-point temperature. They also found that the space-heating consumption varied between apartments by a factor of 80 , which emphasises the effect of occupant behaviour on the outcome of a renovation.

Thomsen et al. (2016) describe another energy renovation in a multi-storey residential building where the energy consumption and indoor climate was estimated using measurements, calculations made in the program Be10, and questionnaires aimed at evaluating the experience and satisfaction of the tenants. Here they achieved a $31 \%$ reduction in the consumption for heating and hot water. However, they stress that it is often the non-energy benefits of a renovation, such as improved indoor climate, that determine whether the occupants find the renovation to be a success, not the actual energy savings. Considering energy saving as an isolated goal is very common in economic evaluations of building renovation and also in the field of energy efficiency promotion. However, most house owners have a broader perspective that influences their decision-making, which is why, when a renovation is evaluated or promoted, it can be beneficial to include other aspects, such as increased comfort, upgrading building elements, and the increased value of the property (Bartiaux et al. 2014; Galvin and Sunikka-Blank 2013; Wilson et al. 2015). Risholt et al. (2013) describe a case study where the sustainability of two different energy renovation strategies with different ambition levels were evaluated. One of their conclusions was that the choice of the optimal renovation depends on the type of house owner, and that qualitative preferences can be as decisive as quantitative measurements. 
There have been even fewer full-scale case studies where the renovation of a single-family house has been measured. One example is the renovation of two different two-storey single-family houses in the UK described by Gupta and Gregg (2016). Here the focus was on reducing $\mathrm{CO}_{2}$ emissions, and while the renovation reduced emissions by $53 \%$ and $75 \%$, the target was an $80 \%$ reduction. However, a reduction in carbon emissions was not the only benefit, because there was a significant improvement in occupant comfort and satisfaction. Tommerup (2008) describes the renovation of a typical Danish single-family home, where it was shown that the building could be brought up to what was the new-house standard at the time: a consumption of only $12.7 \mathrm{MWh} /$ year. While the study successfully used an actual house to show the potential for improvements in energy consumption and indoor climate, the scope of the study did not include an evaluation of the actual need for renovation of the various building elements or the size of the investment the house owners would face. Without the obstacle of a lack of finance or the need to renovate specific building parts, they were able to perform a more thorough and extensive renovation and force several tasks of maintenance.

The renovation described in this paper is based on more realistic financial conditions faced by building owners. The renovation was mostly paid by the house owners themselves, so the relevance of the renovation and the overall cost were central for its success. Although the effect of the renovation on energy consumption was evaluated based on measurements, the scope of the renovation was not limited to reducing this. The aim was to upgrade building elements for durability and according to the house owners' wishes and to improve the indoor climate. Moreover, the evaluation of the cost of the renovation was not based only on direct energy savings, but also on an estimation of the increase in the value of the house.

\subsection{Aim}

This paper evaluates the renovation of a typical Danish single-family house with a holistic focus, taking into account the durability of building elements, the improved function and value of the house, and the reduction in energy consumption.

The renovation is evaluated through simulations and measurements made in the house before and after the renovation. The aim is to show that it is possible to renovate the house in a relevant way and thereby reduce energy consumption for heating significantly and improve the indoor climate while keeping the scope of the renovation economically feasible from the house owners' perspective.

This paper provides a relevant contribution because it presents an economically realistic renovation of a representative Danish single-family house that updates the house with regard to maintenance, energy consumption, indoor climate and functions. It also documents the results through measurements and simulations, contributing to the knowledge about the results of renovations of single-family houses in general. 


\section{House description}

The original house was built in 1965. It was extended by $55 \mathrm{~m}^{2}$ in 1975 , bringing the area up to $160 \mathrm{~m}^{2}$. Figure 1 shows the layout of the house, with the rooms numbered for future reference. Apart from this extension, and a new kitchen in 1985 that included some structural changes in rooms 06 and 07, the house has not been renovated or been the subject of significant maintenance. The house is located in a suburb to Copenhagen with relatively high house prices. This is a benefit for the renovation, because a house in an area with very low market value would not increase so much in value due to renovation.

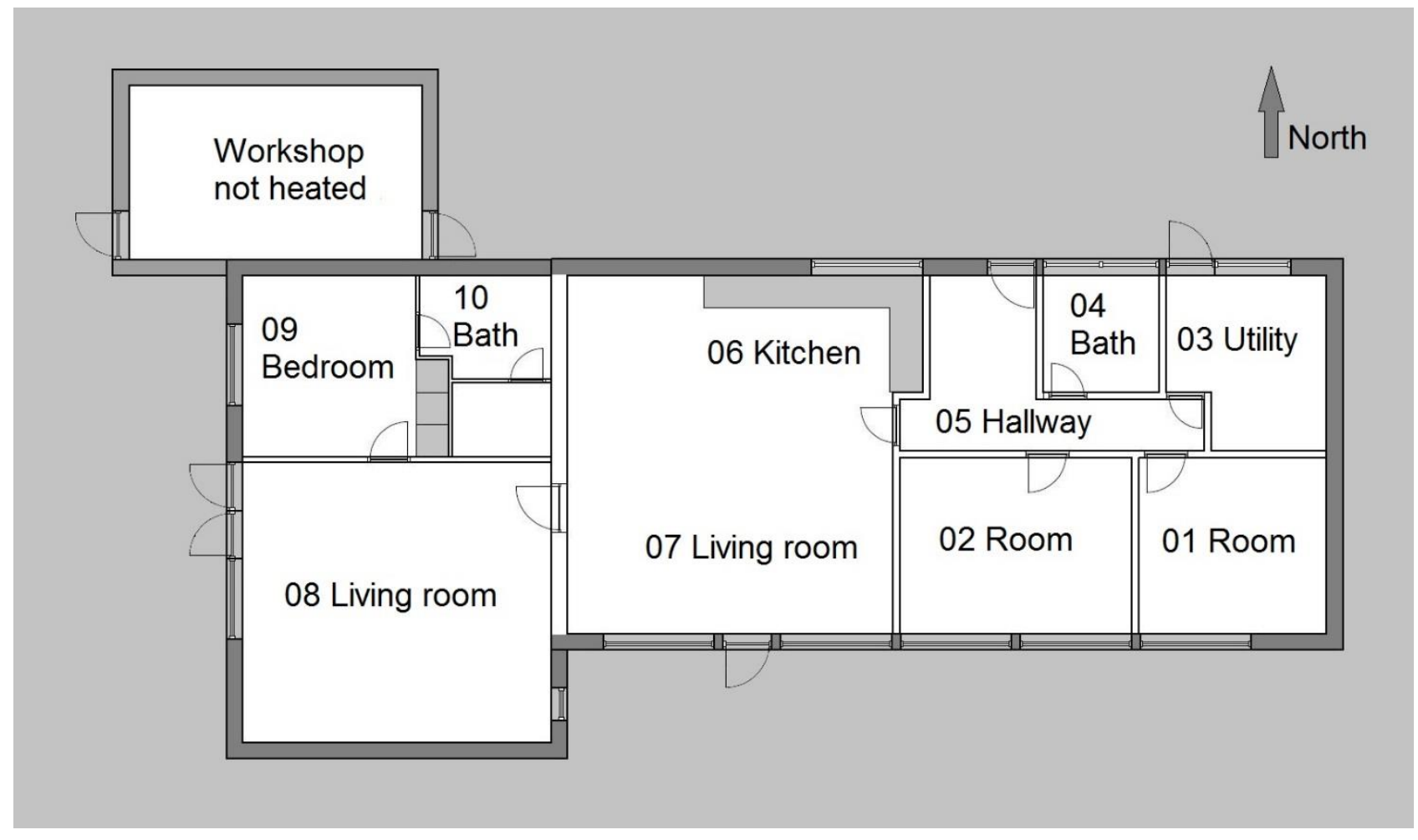

Figure 1 - Plan of the house. The extension built in 1975 consists of rooms 08-10.

The house was built with a double wall in masonry insulated with expanded clay clinker (thermal transmittance about $0.085-0.09 \mathrm{~W} / \mathrm{m}^{2} \mathrm{~K}$ ) in the cavity of the original house and $80 \mathrm{~mm}$ mineral wool insulation in the extension. The roof is double-sloped at an angle of approximately $14^{\circ}$ (see Figure 2 ), and in most of the house the rooms are open up to the rafters. The roof was insulated with approximately $100 \mathrm{~mm}$ mineral wool (thermal transmittance about $0.49 \mathrm{~W} / \mathrm{m}^{2} \mathrm{~K}$ ) and the cladding was corrugated fibre cement. The windows were single layer with a secondary single uncoated pane, and the doors were also the original ones from 1965. The house also had a skylight over the entrance hall, consisting of translucent fibre-reinforced polyester in the same shape as the roof cladding and an original skylight dome in the original bathroom (room 04). The ground slab was insulated with $50 \mathrm{~mm}$ mineral wool. All thermal transmissions are shown in Table 1. 

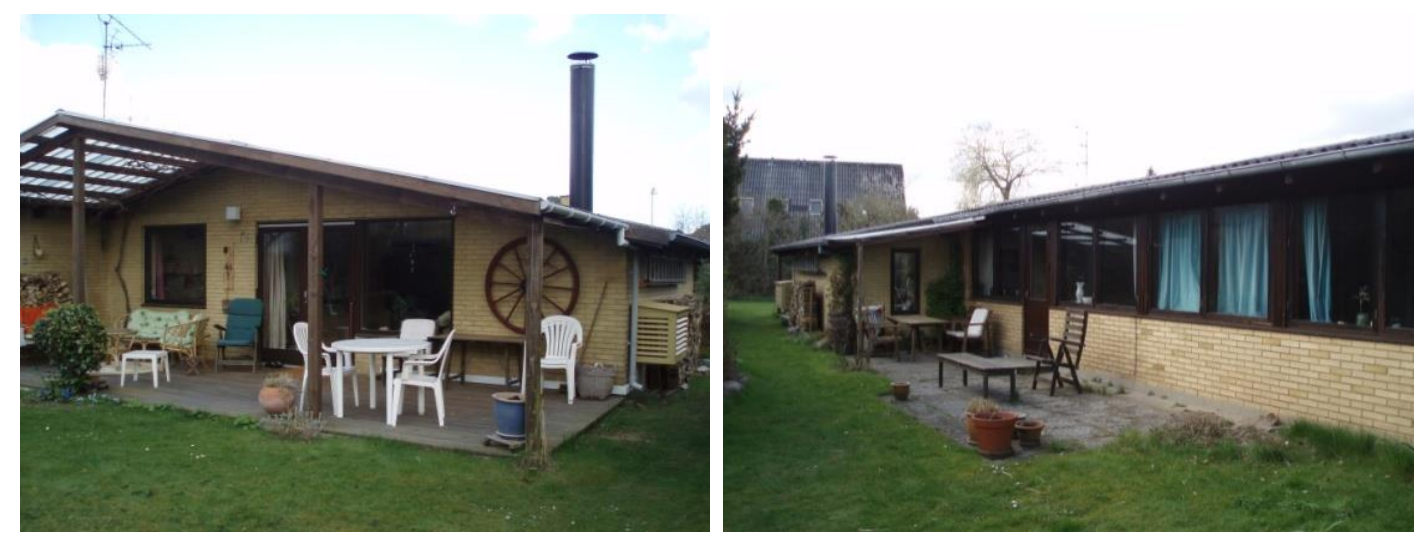

Figure 2 - The house before the renovation as seen from west and southeast.

The house had a number of different heat sources. The original part of the house was heated by a gas boiler from 2003. The extension was heated using an electric convectional heater from 1975 and a heat pump from 2012, supplemented on cold days with a wood-burning stove also from 2012. The house had no mechanical ventilation.

The house was found through a process of advertisement for houses in need of renovation, and selected based on it being representative and having potential. Beside this, the house owners had to have enough money and the will to perform a renovation, as they would have to pay for everything except the advice from the authors (only concerning energy) and reduced price on some building materials with maximum 30000 DKK. For more details on the process, see Bjørneboe et al. (2016). The house owners are 2 adults, both retired, with one adult child who no longer lives with his parents. They have lived in the house for more than 30 years.

\subsection{The renovation}

The scope of the renovation was decided by the house owners based on professional advice using a One-stop-shop or full-service concept whereby the house owners are guided through the whole renovation process by one company or contact person. The renovation took into consideration the remaining service life of the building components, the need for functional improvements in the house at the time and in the near future, and the opportunity to implement energy improvements. Simulations and calculations were used to estimate the possible savings each measure could achieve. The renovation concept and process is further described by Bjørneboe et al. (2016).

The renovation was carried out in the summer of 2013 and included the following measures, which were all implemented during this renovation:

- The replacement of all windows with 3-layer energy windows. One of the two windows in room 04 (Bathroom) was removed and replaced with a brick wall with $100 \mathrm{~mm}$ insulation

- The replacement of all external doors (in rooms 03, 05, 07 and 08) 
- The raising of the roof construction to allow for more insulation ( $365 \mathrm{~mm}$ in total) and make room for ventilation. The replacement of the cladding of corrugated fibre cement

- The replacement of the existing skylights with more energy-efficient light tunnels

- The installation of a mechanical ventilation system with heat recovery

- The replacement of the cavity insulation in the façade

Once the renovation of the building envelope was complete, an internal renovation was also carried out, in which rooms 03 and 04 were replaced and updated. This was carried out in the spring of 2014.

Table 1 - The assumed thermal transmission of the affected building elements before and after the renovation.

Thermal transmission of building parts

\begin{tabular}{ccc}
\hline & $\begin{array}{c}\text { Before renovation } \\
\mathrm{W} / \mathrm{m}^{2} \mathrm{~K}\end{array}$ & $\begin{array}{c}\text { After renovation } \\
\mathrm{W} / \mathrm{m}^{2} \mathrm{~K}\end{array}$ \\
\hline Windows & $1.07-4.80(2.74)$ & $0.63-0.87(0.71)$ \\
Doors & $2.00-3.54(2.71)$ & $0.70-1.39(0.91)$ \\
Roof & 0.49 & 0.10 \\
Skylights & $3.52-4.93(4.23)$ & 1.3 \\
Façade & 0.67 & 0.37 \\
\hline
\end{tabular}

Note: The before-values are estimates based on the house, the construction and traditional building practices. The after-values include product information on the new materials and building parts. For windows, doors and skylights, where the value covers more than one type, the table shows [min-max (average)] thermal transmission.

\section{Method}

To document the effect of the renovation on energy consumption and indoor climate, a number of measurements were made before and after the renovation, see Table 2 .

To put the house and the renovation in a national context, the energy level of the house before and after the renovation was determined by simulation in the program Be10 (SBi Danish Building Research Institute 2006, 2008) in accordance with the Danish Building Regulations (Danish Transport and Construction Agency 2015). This program was chosen because it is the standard program for determining the energy level of buildings in Denmark. The energy level found using this program enables comparison with all other houses calculated in a similar way, and helps to place the house on the scale used in the national scheme for energy performance certificates (EPC) for buildings. However, the program simulates using a single-zone model, which (Vanhoutteghem and 
Svendsen 2014) underestimates the need for space heating. Moreover, this program does not include user behaviour, so the energy level found cannot be directly compared to the energy consumption measured. The program calculates the energy consumption for heating and cooling, excluding electricity used for other purposes, such as lighting and appliances.

Table 2 - Measurements made in the house

\section{Measurements}

Single measurements and readings made before and after renovation
Thermographic pictures

Blower-door pressurisation

The total electricity consumption over a 12 -month period

The total gas consumption over a 12-month period

The house owners' opinions on the renovation were determined through interviews

Logging of temperature every $10-15 \mathrm{~min}$ in all rooms

Continuous measurements made for a year before and after the renovation

Readings made by the house owner in the year after the renovation

\section{Date and time of the reading}

The total electricity consumption shown by the electricity meter (for heating and appliances)

The total consumption shown by the gas meter (for heating and hot water)

Electricity consumption of the heat pump measured by an energy-cost meter (SparOmeter)

Electricity consumption of electric convectional heater measured by an energy-cost meter

Notes specifying when the house was empty, when the wood-burning stove was in use etc.

Once all relevant values were obtained, they were analysed and compared:

- The energy consumption measured before and after the renovation was weighted according to climate using heating degree days (HDD). 1 degree day means that for 1 day the temperature was 1 degree lower than the indoor temperature. Degree days can be used as a simple measure of the buildings exposure to cold, and thereby the weather influence on the heating demand. See e.g. (Bromley 2008) for further explanation.

- The contribution from the wood-burning stove before and after renovation was estimated and included in the consumption measured 
- The energy saving achieved was found by comparing the energy consumption before and after the renovation

- The energy level calculation made in the program BE10 was used to assign the house an energy label in accordance with the Danish Energy Performance Certificate (EPC), which is part of the European Energy Performance of Buildings Directive (EPBD)

- A simulation model of the house before and after renovation was made using the building simulation software BSim (SBi Danish Building Research Institute 2015)

- The increase in comfort and changes in user behaviour were evaluated based on the temperatures measured and interviews with the house owners. The aim was to achieve comfortable temperature levels in the opinion of the current owners in their daily use of the house. To determine general temperature comfort is not within the scope of the study.

- The financial saving was estimated based on the energy savings measured

- The cost of the renovation was evaluated based on the size of the investment and the increased house value estimated by a real estate agent and the house owners' bank

- The overall result was evaluated based on energy, indoor climate, cost and opinions of the house owners

\section{Measurements}

The measurements on the single-family house were made during a before-period from May 2012 April 2013 and an after-period from December 2013 - November 2014.

A professional company was hired to take infrared pictures of the house before and after the renovation to identify thermal bridges and sources of large heat losses. Both days had similar weather conditions, with wind about 4m/s from NV (Danish Meteorological Institute DMI 2012, 2013) and temperatures measured at the location of $-0.4{ }^{\circ} \mathrm{C}$ to $-1.4{ }^{\circ} \mathrm{C}$ at the time.

The air tightness of the house was examined before and after renovation using the fan pressurisation method in accordance with DS/EN 13829 (Dansk Standard 2001). This was done using a blower door mounted in the main entrance door in room 05 (see Figure 1) and determining the volume flow at $50 \mathrm{~Pa}, \mathrm{q}_{50}\left[\mathrm{l} / \mathrm{s} \mathrm{m}^{2}\right]$. From this value, the infiltration (also known as air leakage into the building) was calculated (SBi Danish Building Research Institute 2008) as:

$$
0.04+0.06 \cdot q_{50}
$$

As the infiltration covers the unintentional air leakage into the building e.g. through cracks, it is important to know the actual size of infiltration when calculating building energy use, as this can have a significant impact.

The total energy consumption of the house before the renovation was taken from the energy bills for electricity and gas provided by the house owners. We decided to look only at the consumption 
over one year before the renovation, and no further back, because the house had a heat pump installed just before this period, which would confuse the results. The house owners explained that they had problems heating up the occupied spaces before the heat pump was installed, which means that the indoor climate and energy consumption was greatly affected by this improvement. The energy consumption measured for the period of 12 months after the renovation was determined from readings of the electricity meter and gas meter in the house.

HOBO U10 Temp/RH and HOBO U12 Temp/RH/Light/EXT loggers were set up in every room and used to log the temperature every $10-15 \mathrm{~min}$. The loggers have an accuracy of $\pm 0.35^{\circ} \mathrm{C}$ from $0{ }^{\circ} \mathrm{C}$ to $50{ }^{\circ} \mathrm{C}$. The house was inhabited throughout the project, so the loggers were placed with the objective to achieve minimum inconvenience rather than optimal measurement. They were generally positioned on internal walls about 1.5-2 $\mathrm{m}$ from the floor, not close to any heat sources or in direct line of solar radiation. They took measurements in the periods both before and after the renovation.

The owners of the house were very much involved in the project, which made it possible to obtain more detailed data on the energy consumption after the renovation. Energy-cost meters to measure the electricity consumption were installed on the supply for the heat pump and for the electrical heating in room 10, and the house owners noted down the consumption every day. The total electricity and gas consumption was also read from the energy meters on a daily basis. The house owners made these readings almost every day for a year after the renovation, and also made a note of whether the house was empty, whether the wood-burning stove was in use, and anything else that might have a significant effect on the energy consumption that day.

\section{$5 \quad$ Evaluation and analysis}

The energy consumption before and after the renovation were compared by weighting the values using degree days provided by the Danish Technological Institute (Teknologisk Institut 2015). The standard year was set to 2906 degree days, the before-period had 2852 degree days, and the afterperiod had 2038 degree days. The energy consumption was split into weather-independent use (WIU) and weather-dependent use (WDU). WIU consists of consumption for hot water and electricity used for other purposes than heating. The WIU for hot water was based on gas consumption during a period in the summer when there was no heating in the house. The WIU of electricity was found by subtracting the measured use for heating from the total consumption. The same consumption was assumed for WIU before and after the renovation, although this calculation of WIU was only possible for the period after the renovation, because the specific electricity use for heating was not measured before. However, since the WIU is not affected by the weather, it should not have changed much due to the renovation. The weather-corrected energy consumption (WCEC) in the given period was calculated as follows:

$$
W C E C=W D U \cdot \frac{2906}{\text { degree days in period }}+W I U
$$


The contribution from the wood-burning stove was based on estimates. The house owners estimated the use to be about $4 \mathrm{~kg}$ wood on an average day when the wood-burning stove was in use. The average specific energy of the wood is set to $4.1 \mathrm{kWh} / \mathrm{kg}$ (træfælderen.dk 2011), giving an average contribution from the wood-burning stove of:

$$
{ }_{4} \mathrm{~kg} / \text { day } \cdot 4.1 \mathrm{kWh} / \mathrm{kg}=16,4 \mathrm{kWh} / \text { day }
$$

The number of days the wood-burning stove was in use was only registered after the renovation. Based on this, an estimate of its use before the renovation was made based on degree days, because the wood-burning stove is used in cold weather as a supplement to the other heating sources:

$$
\text { use before }=\text { use after } \cdot \frac{\text { degree days before }}{\text { degree days after }}
$$

This number has a large degree of uncertainty due to the simplicity of the estimation. However, the stove contributes with less than 3\% (1.45-2.65\%) of the total energy consumption, which means that uncertainty about the exact contribution will not have a significant effect on the total result. The estimated use can be assumed to be conservative, because the need to use the wood-burning stove should decrease independently of the weather, after the house was renovated and the relative heat loss was reduced.

The increase in comfort and changes in user behaviour were evaluated based on the temperatures measured. The average and extreme temperatures were determined for each room, and patterns in the fluctuations were identified. The conditions before and after the renovation were compared to identify changes.

The overall result of the renovation was evaluated based on the energy savings achieved, the improvements in indoor climate according to the measurements and the house owners, and the cost of the renovation.

The house was simulated in the program BSim (SBi 2015), where it is possible to model indoor climate and energy consumption both at room level and in total based on a 3D model. The simulation modelled the building for a year before and after the renovation, with weather data reflecting the actual conditions at the time and place of the measurements taken at the house. This data was provided by the Danish Meteorological Institute (DMI). The model was mostly based on registrations made in the house in terms of geometry, building components, installations and userdefined settings such as set-points for heating, which was based on an average of the temperatures that were measured in each room. 


\section{Results}

\subsection{One-time measurements}

The entire house was examined using an infrared camera to create thermographic pictures indicating the sources of heat loss from the house before and after the renovation. Figure 3 shows a representative corner of the house before and after the renovation. On the before-picture, a large triangle with a higher temperature (about $0.5^{\circ} \mathrm{C}$, the coldest part is about $-2{ }^{\circ} \mathrm{C}$ ) indicates that the insulation has partly collapsed and is no longer evenly distributed in the wall. Moreover, the window itself has a higher temperature (about $1.8^{\circ} \mathrm{C}$ ) indicating significant heat loss. In the after-picture, the temperature of the wall and window is much lower (about $-13^{\circ} \mathrm{C}$ on the window and $-16{ }^{\circ} \mathrm{C}$ to $-4{ }^{\circ} \mathrm{C}$ on the wall), and the shape of the warmer area under the roof indicates that the higher temperature here could be due to this part of the wall being more sheltered from wind and sky radiation.
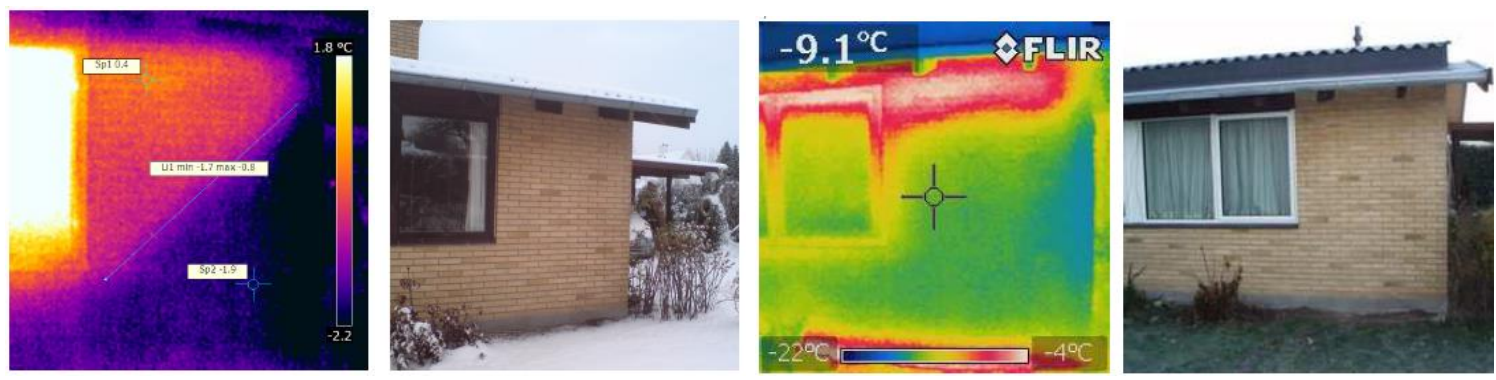

Figure 3 - Examples of infrared pictures of the same corner of the house before and after the renovation. The scale on the before picture is -2.2 to $+1.8^{\circ} \mathrm{C}$, the after is -22 to $-4^{\circ} \mathrm{C}$.

Table 3 - Volume flow through leaks in the building envelope at a pressure of $50 \mathrm{~Pa}$, measured according to DS/EN 13829 (Dansk Standard 2001). The volume flow is compared to the requirements for new buildings according to the Danish Building Regulations (Danish Transport and Construction Agency 2015).

\begin{tabular}{|c|c|c|c|c|c|}
\hline & \multicolumn{2}{|c|}{ Measured } & \multicolumn{3}{|c|}{$\begin{array}{l}\text { Building Regulations, new } \\
\text { buildings }\end{array}$} \\
\hline & Before & After & 2010 & 2015 & 2020 \\
\hline & $\mathrm{l} / \mathrm{s} \cdot \mathrm{m}^{2}$ & $I / s \cdot m^{2}$ & $\mathrm{I} / \mathrm{s} \cdot \mathrm{m}^{2}$ & $\mathrm{I} / \mathrm{s} \cdot \mathrm{m}^{2}$ & $\mathrm{l} / \mathrm{s} \cdot \mathrm{m}^{2}$ \\
\hline $\begin{array}{l}\text { Volume flow through leaks in building } \\
\text { envelope, } q_{50}\end{array}$ & 2.5 & 0.8 & 1.5 & 1.0 & 0.5 \\
\hline Infiltration & 0.19 & 0.09 & & & \\
\hline
\end{tabular}


The results of the pressurisation test are shown in Table 3, and compared to the requirements for new buildings according to the Danish building code (there being no current requirements for tightness in the case of renovation). The table also shows the infiltration calculated based on the results. As the average house of this type and age has an infiltration of about $0.45 \mathrm{l} / \mathrm{s} \cdot \mathrm{m}^{2}$ (Teknologisk Institut 2007), the infiltration in this house was very low before the renovation, and it was further decreased by the renovation.

\subsection{Energy consumption}

The total energy consumption values measured in the house before and after the renovation are shown in Table 4. Once the consumption is weighted using degree days, the total energy consumption before and after renovation can be compared. According to the measurements, the renovation reduced the total energy consumption by $23 \%$.

Table 4 - The measured energy consumption of the house before and after the renovation.

\begin{tabular}{|c|c|c|c|c|c|}
\hline \multicolumn{6}{|l|}{ Energy consumption } \\
\hline & & Before & After & $\begin{array}{l}\text { Differenc } \\
\text { e }\end{array}$ & $\begin{array}{l}\text { Differenc } \\
\text { e [\%] }\end{array}$ \\
\hline $\begin{array}{l}\text { Energy consumption, } \\
\text { measurement }\end{array}$ & kWh & 27390 & 17664 & 9725 & $36 \%$ \\
\hline Electricity & kWh & 9966 & 7070 & & \\
\hline Gas & kWh & 17424 & 10594 & & \\
\hline $\begin{array}{l}\text { Assumed contribution from } \\
\text { wood-burning stove }\end{array}$ & kWh & 574 & 410 & & \\
\hline Degree days in the period & - & 2852 & 2038 & & \\
\hline Weather-independent use & kWh & 9286 & 9286 & & \\
\hline Electricity & $\mathrm{kWh}$ & 5776 & 5776 & & \\
\hline Gas & kWh & 3510 & 3510 & & \\
\hline $\begin{array}{l}\text { Weather-dependent use } \\
\text { (Heating) }\end{array}$ & kWh & 18677 & 8788 & & \\
\hline Electricity & kWh & 4190 & 1294 & & \\
\hline Gas & kWh & 13914 & 7084 & & \\
\hline $\begin{array}{l}\text { Weather-corrected energy } \\
\text { consumption }\end{array}$ & kWh & 28317 & 21817 & 6500 & $23 \%$ \\
\hline
\end{tabular}


Prices for electricity and gas vary over time, so to get an idea of the economic saving an estimated standard price was used. The price of gas is estimated to $8.9 \mathrm{DKK} / \mathrm{m}^{3}$, based on the average cost in this part of Denmark during the year when the house was renovated. The price of electricity was set to $2.1 \mathrm{DKK} / \mathrm{kWh}$, including all charges, based on the information from the electricity bill for the house in the year 2013/2014. When these prices are applied to the weighted energy consumption before and after, the total saving was found to be about DKK 8400 per year on electricity and gas.

The program BSim was used to simulate the energy consumption for heating the house. A comparison of the energy consumption for heating found through simulations and measurements in the house is shown in Table 5. It is not necessary to weight these values according to temperature to enable comparison, because weather data from the period were used in the simulation model. While there is a noticeable difference between the size of the energy consumption found in the simulation compared to the measurements, the saving of $53 \%$ of the heating consumption achieved is close to the $58 \%$ calculated in the simulation model.

Table 5 - Comparison of the measured and simulated energy consumption for heating the house before and after renovation.

\begin{tabular}{lccccc}
\hline Energy for heating & & & & \\
\hline Consumption & & Before & After & Difference & $\begin{array}{c}\text { Difference } \\
{[\%]}\end{array}$ \\
\hline $\begin{array}{l}\text { Measured energy consumption } \\
\begin{array}{l}\text { Simulated energy consumption } \\
\text { (BSim) }\end{array}\end{array}$ & kWh & 18677 & 8788 & 9889 & $53 \%$ \\
\hline
\end{tabular}

\subsection{Energy level}

To make it possible to compare the energy level of this house with other houses, the energy level of the house was calculated in the same way as it would be if the house was to receive an energy performance certificate (EPC) in accordance with Danish and European requirements (Retsinformation 2016). The result of the energy level calculation is shown in Table 6.

Table 6-Energy level of the house calculated in Be10

\begin{tabular}{lccccc}
\hline Energy level calculation & & & & \\
\hline & & Before & After & Difference & Difference [\%] \\
\hline Energy level & $\mathrm{kWh} / \mathrm{m}^{2} /$ year & 192.8 & 120.8 & 72 & $37 \%$ \\
Corresponding energy label & - & $\mathrm{E}$ & $\mathrm{C}$ & & \\
\hline
\end{tabular}

The energy level includes heating, hot water and ventilation based on standard values, and does not include electricity for other purposes, because this depends very much on the occupant of the 
building. The EPC has a scale from G $\left(>240+6500 / \mathrm{AWh} / \mathrm{m}^{2}\right.$ year, $>281 \mathrm{kWh} / \mathrm{m}^{2}$ year for a house of this size) to $A 2020$ ( $20 \mathrm{kWh} / \mathrm{m}^{2}$ year). Before the renovation, the house had an EPC rating of $E$, which is very common for a house of this type and age (Energistyrelsen and Danish Energy Agency 2016). After the renovation, the house has an EPC rating of C, corresponding to new houses built in 20082010. The renovation also enables the house to receive the rating Renovation class 2 according to the Danish Building Regulations (Danish Transport and Construction Agency 2015).

\subsection{Indoor thermal climate}
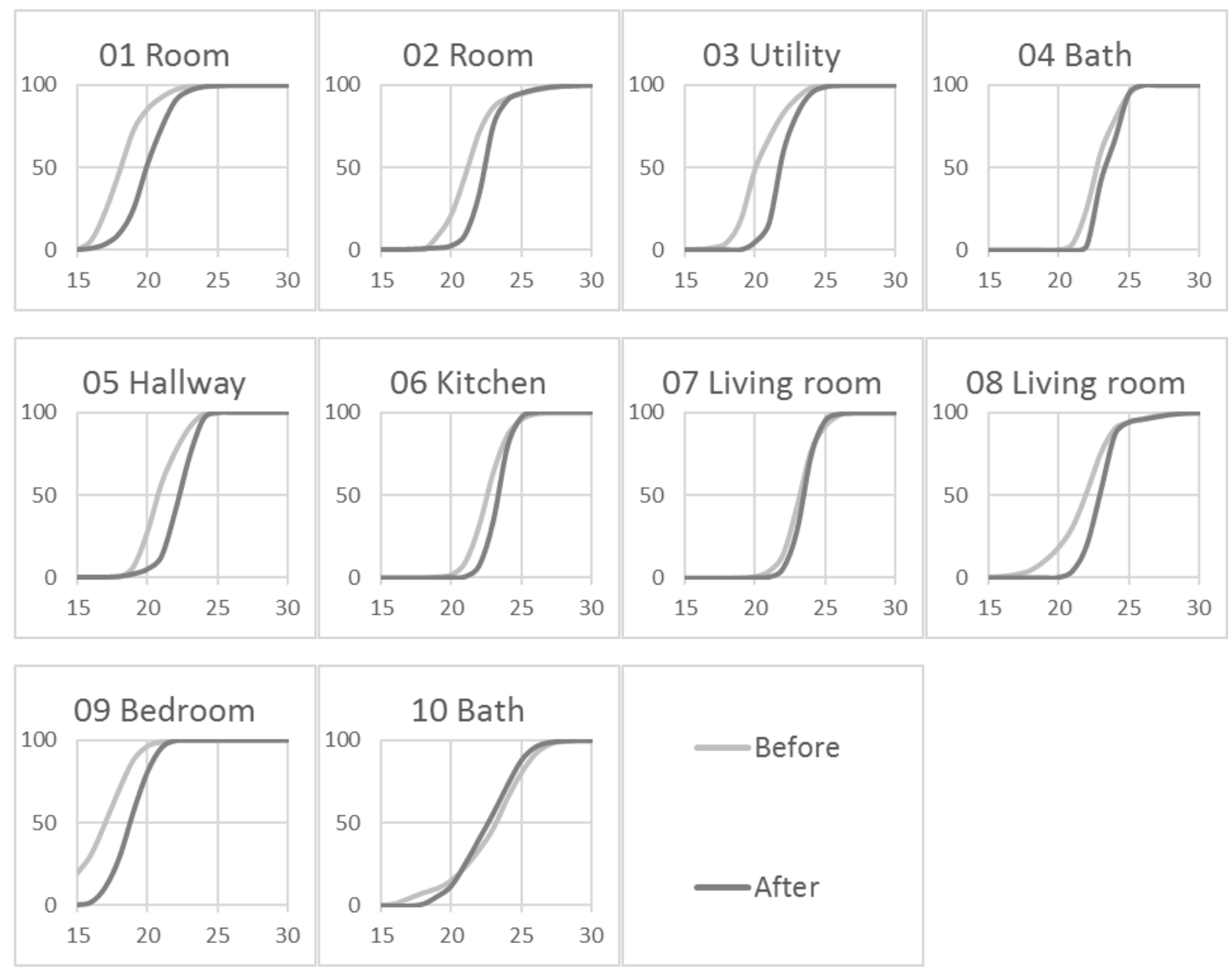

Figure 4 - Cumulative percentage distribution of measured temperatures during the heating period before and after the renovation.

The temperature level in all 10 rooms in the house was monitored for a year before and a year after the renovation, and the cumulative percentage distribution of the values measured during the heating season is shown in Figure 4, the average temperatures and their standard deviation before and after are shown in Figure 5 and Table 7.

The room temperature was regulated by the house owner themselves, based on their preferences. In the rooms most often occupied $(06,07$ and 08 ), the temperature is slightly more even (more 
vertical curve, lower standard deviation), which indicates that it is now easier for the occupants to maintain a steady temperature of about $23^{\circ} \mathrm{C}$. In room 08 , there has been a particular improvement, because the temperature now rarely slips below $20^{\circ} \mathrm{C}$. In the more rarely occupied rooms $(01,02$, 03 and 05), the temperatures before were often low, making it more difficult to maintain a comfortable temperature in the occupied rooms and avoid draughts. After the renovation, the temperature in these rooms has increased, making them more usable and reducing draughts in the house. In the bedroom (09), the occupants prefer a lower temperature, but before the renovation the temperature was below $15{ }^{\circ} \mathrm{C}$ almost $20 \%$ of the time. Such very low temperatures during the heating season can cause problems with condensation and mould, which is why it is much better to keep the rooms heated at all times.

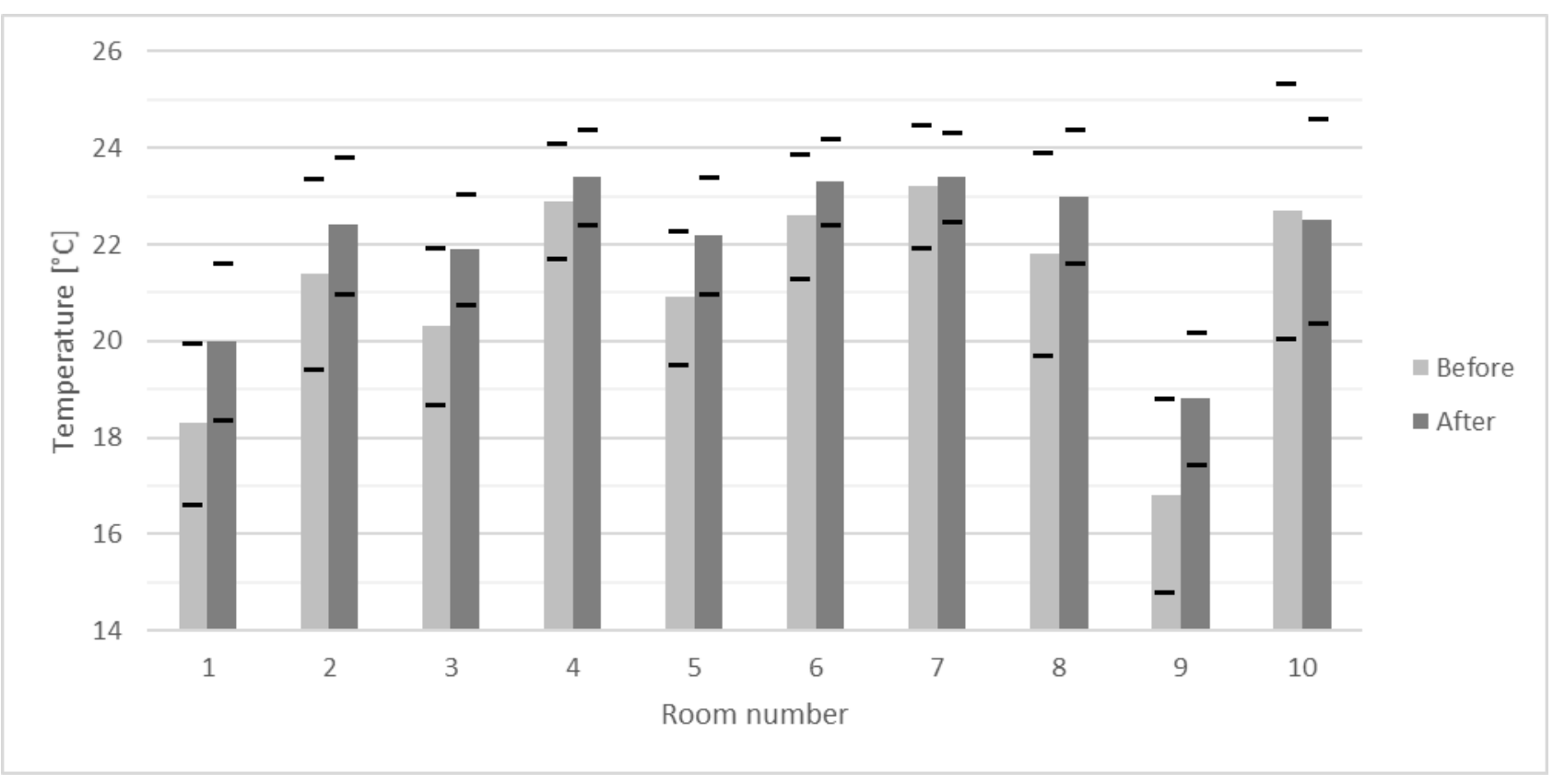

Figure 5 - The average temperature and standard deviation of temperature in the 10 rooms before and after the renovation.

In average, the temperature has increased by $1.01{ }^{\circ} \mathrm{C}$ in the rooms. A paired t-test on the average of temperature measurements before and after gives a $P$ value of 0.0014 , so the difference in temperature can be considered to be very statistically significant. The $95 \%$ confidence interval is 1.5 to -0.5 . When performing an unpaired t-test for the measurements of each room, all $P$ values are below 0.0001, so the difference can be determined as extremely statistically significant. However this calculation cannot prove that this rise in temperature is a general consequence of this type of renovation, as a number of factors can have contributed to the increase.

Firstly, the temperature inside could be the result of changes in the outside temperature. The average of the temperature measured outside the house was $3.4{ }^{\circ} \mathrm{C}$ higher in the winter after the renovation compared to the year before (average $4.6^{\circ} \mathrm{C}$ before $(-10.5$ to 22.0$), 8.0^{\circ} \mathrm{C}$ after $(-5.9$ to 23.3)). An evaluation of a shorter period of 3 days was made, in order to assess whether similar 
outdoor conditions would eliminate the indoor temperature difference. Data was selected for periods during the before and after year, where the weather conditions were similar, concerning downpour, hours with sunshine, wind speed and direction and temperature development (when comparing each outdoor temperature measurements from the before period with the corresponding temperature in the after period, the difference is never more than $1.4{ }^{\circ} \mathrm{C}$, and only $0.4^{\circ} \mathrm{C}$ difference in either direction in average). When looking at the indoor temperatures during these periods, there has been a temperature increase in all rooms, $1.3^{\circ} \mathrm{C}$ in average and up to 2.3 ${ }^{\circ} \mathrm{C}$ (in 06 Kitchen). A paired t-test found this difference to be extremely statistically significant with a $P$ value below 0.0001 . The analysis of this period suggests that the difference in temperature measured during the year before and after the renovation is not caused by changes in the outside temperature.

Table 7 - Average measured temperatures in all rooms in the house during the heating season before and after the renovation.

\begin{tabular}{|c|c|c|c|c|c|c|c|c|c|c|c|}
\hline Room number & $\#$ & 01 & 02 & 03 & 04 & 05 & 06 & 07 & 08 & 09 & 10 \\
\hline $\begin{array}{l}\text { Average temperature } \\
\text { before }\end{array}$ & ${ }^{\circ} \mathrm{C}$ & 18.3 & 21.4 & 20.3 & 22.9 & 20.9 & 22.6 & 23.2 & 21.8 & 16.8 & 22.7 \\
\hline $\begin{array}{l}\text { Average temperature } \\
\text { after }\end{array}$ & ${ }^{\circ} \mathrm{C}$ & 20.0 & 22.4 & 21.9 & 23.4 & 22.2 & 23.3 & 23.4 & 23.0 & 18.8 & 22.5 \\
\hline Difference & ${ }^{\circ} \mathrm{C}$ & 1.7 & 1.0 & 1.6 & 0.6 & 1.3 & 0.7 & 0.3 & 1.2 & 1.9 & -0.2 \\
\hline $\begin{array}{l}\text { Standard deviation, } \\
\text { before }\end{array}$ & ${ }^{\circ} \mathrm{C}$ & 1.67 & 1.98 & 1.62 & 1.2 & 1.38 & 1.29 & 1.27 & 2.11 & 2 & 2.63 \\
\hline Standard Deviation, after & ${ }^{\circ} \mathrm{C}$ & 1.63 & 1.42 & 1.14 & 1 & 1.21 & 0.9 & 0.91 & 1.38 & 1.37 & 2.12 \\
\hline Difference & ${ }^{\circ} \mathrm{C}$ & 0.04 & $\begin{array}{c}- \\
0.56\end{array}$ & $\begin{array}{c}- \\
0.48\end{array}$ & -0.2 & $\begin{array}{c}- \\
0.17\end{array}$ & $\begin{array}{c}- \\
0.39\end{array}$ & $\begin{array}{c}- \\
0.36\end{array}$ & -0.7 & -0.6 & -0.5 \\
\hline
\end{tabular}

Secondly, the temperature increase varies a lot from room to room, depending on the before temperature and the use of the room. In some of the rooms $(04,06,07$ and 10), the temperature is at the same level before and after the renovation, see Table 7. In these rooms, the renovation resulted in decreased energy consumption, because it now takes less energy to maintain a comfortable temperature. However, in other rooms (01, 02, 03, 05, 08 and 09), the energy consumption has not decreased very much, because part of the potential energy saving is spent on heating the rooms to a higher temperature. This phenomenon where the potential energy saving is used to increase comfort is called the rebound effect. This is very common in connection with renovations, and is often the result when a house was insufficiently heated before the renovation. Although increasing the temperature reduces the achieved energy saving, this is to some degree 
necessary in order to achieve a more uniform temperature throughout the house, thereby reducing internal cold draughts.

\subsection{The house owners' opinion}

Once the renovation had been carried out, the house owners were asked to evaluate the result. In general, they were satisfied with the way the renovation had been carried out and the overall result. With regard to the indoor climate, the house owners experienced a significant improvement as a result of the renovation. They feel the temperature has become less fluctuating, even during night when the heating is turned off in part of the house. They describe the house as being warmer during the winter, and they no longer feel a cold draft from the entrance hall (room 05), which they perceived as a problem before. In the summer, they also experience an improvement. The thick insulation layer in the roof keeps the living room much cooler during the summer.

The house owners have kept many of their old habits from before the renovation. For example, the house is vented through the windows on a daily basis, despite the fact that they find the air quality to be good due to the new mechanical ventilation system, which makes venting redundant. This has a negative impact on the energy consumption after the renovation because it increases the heat loss.

\subsection{Cost of the renovation}

The value of property and cost of renovation are shown in Table 8. Before the renovation in March 2013, the whole property (house and land) was worth about DKK 4.5 million (about EUR 600,000) according to their mortgage bank.

The renovation of the house cost an investment of about DKK 850,000 for the first part in 2013, including the building envelope and the ventilation system, and about DKK 450,000 for the second part in 2014, including rooms 03 and 04 . The total investment was about DKK 1.3 million.

After the renovation, a new evaluation of the value of the house was made, by the mortgage bank to increase the mortgage and by a local real estate agent (both in September 2014). Both parties found the house to have a value of about DKK 5.7 million after the renovation, an increase of DKK 1.2 million compared to its value before the renovation.

The increase in housing prices were calculated according to the price index for sales of property, specifically one-family houses in the quarters where the evaluations took place (Statistics Denmark 2016). According to these numbers, the value of the house, disregarding the renovation increased with about 200000 DKK. However, even taking this into account, the increased value of the house due to renovation is estimated to be about DKK $1,000,000$. This increase in price corresponds to 
about $77 \%$ of the cost of the renovation. In addition to this, there is now a reduced expenditure for electricity and gas of about DKK 8,400 per year1.

Table 8 - Value of property and cost of renovation

\begin{tabular}{|c|c|c|c|c|}
\hline \multicolumn{5}{|l|}{ Value of property } \\
\hline & & $\begin{array}{l}\text { Before } \\
\text { renovation }\end{array}$ & $\begin{array}{l}\text { After } \\
\text { renovation }\end{array}$ & Difference \\
\hline & & March 2013 & September & \\
\hline & & ( $1^{\text {st }}$ quarter) & 2014 & \\
\hline & & & ( $3^{\text {rd }}$ quarter) & \\
\hline Evaluation by mortgage bank & DKK & 4500000 & 5700000 & 1200000 \\
\hline Evaluation by real estate agent & DKK & - & 5700000 & \\
\hline Price index ${ }^{a}$ & - & 86.1 & 90.9 & \\
\hline $\begin{array}{l}\text { Approx. value increase based on } \\
\text { price index }\end{array}$ & DKK & & & 200000 \\
\hline $\begin{array}{l}\text { Resulting value increase due to } \\
\text { renovation }\end{array}$ & DKK & & & 1000000 \\
\hline \multicolumn{5}{|l|}{ Cost of renovation } \\
\hline & & Part one & Part two & Total \\
\hline Renovation cost & DKK & 850000 & 450000 & 1300000 \\
\hline
\end{tabular}

\section{Discussion}

\subsection{Accuracy of measurements and simulations}

A number of factors influence the accuracy of the measurements. The fact that the house has a wood-burning stove makes the prediction of the savings less clear, because the total use of the wood-burning stove is unknown. Its wood consumption and energy contribution are based on rough estimates, and its use is based on information from the house owners collected after the renovation. However, the contribution from the wood-burning stove only covers about $3 \%$ of the total energy consumption of the house, which lessens its effect on the results. A more precise determination of

1 The average yearly disposable income in Denmark is about 220,000 DKK. For more information on the overall economy of Danish households, see (Statistics Denmark 2015). 
the energy contribution from the wood-burning stove would therefore not make a significant difference to the total result.

Another thing that affects the accuracy is the method of weighting energy use by degree days. Although this is a commonly used method for weighting energy needs, it is still a relatively simple method, because it is based solely on temperatures and does not include, for example, the effect of sun and wind. The weighting of the energy use is also very dependent on the division between weather-dependent and weather-independent use. Due to the detailed measurements of the energy consumption for heating carried out after the renovation, the remaining electricity consumption has little uncertainty. However, the figures for the remaining electricity consumption before the renovation are more uncertain, because these are also based on the values from after the renovation. The hot water consumption, which is the weather-independent part of the gas consumption, is based on the values measured during a summer period with no heating. While the value is based on average figures from measurements in the actual house, there is still some uncertainty, because the consumption changes continuously.

The temperature data was collected by putting a HOBO-logger in every room of the house. Since the measurements were made over a long period of more than two years and the house was inhabited all the time, the loggers were located to avoid inconvenience. The temperatures measured therefore are not an accurate documentation of the operative temperature in the house. However, the loggers remained in the same place throughout the period, so their data gives a good account of the size of temperature fluctuations over time and the difference in temperature levels before and after the renovation.

The accuracy of the simulations was also affected by various factors. While the model was built to come as close to the actual conditions as possible, it still required a lot of assumptions, e.g. about material properties and building systems, and the geometry is slightly simplified.

\subsection{Discussion of results}

Most of the measurements carried out on the house show that the house has been improved through the renovation, because the house became warmer and more air tight. The house owners are satisfied with the result of the renovation, because they can feel an increase in comfort, which are important factors to determine the success of a renovation (Thomsen et al. 2016). The reduction in the total energy consumption was about $23 \%$, and the energy consumption for heating was reduced by about $53 \%$. This is not far short of the $58 \%$ savings found through the simulation of the house. Due to measurements made in the house, it was possible to make a simulation model that was fairly close to the actual conditions, which can explain why the achieved saving are close to that found through simulations. A saving of about $50 \%$ on the energy consumption for heating confirms that there is a large potential for achieving energy savings in this part of the building stock through renovation. It is also on the same level as the savings achieved by (Tommerup 2008), who measured 
on the renovation of a similar single-family house, and found a reduction of $54 \%$ on heating consumption.

As the house owners were very much engaged in the renovation, and were made aware of their energy consumption on a daily basis when reading of meters, it is possible that part of the energy saving achieved are due to changes in behaviour and not the renovation itself. In favour of this, is the fact that the house owner started to gradually change old energy consuming light bulbs to more efficient LED. However, other things did not change, such as the house owner continuing their daily venting routine despite the new ventilation system. Although the awareness may have had an effect on the size of the energy saving, it is not deemed to be significant. Especially as the measurements show that part of the energy saving has been consumed by increased comfort. Before the renovation, a large part of the house was allowed to have very low temperatures during the winter, which resulted in cold draughts in the house. After the renovation, the house is easier and cheaper to heat, which creates the option of keeping a more even indoor temperature in the whole house.

All too often, the feasibility of an energy renovation is judged solely by calculating the simple payback time for the improvements. However, this approach is problematic, as it can be beneficial to include other aspects as well, as suggested by (Bartiaux et al. 2014; Wilson et al. 2015). This renovation included purposes other than reducing energy consumption, such as replacement of worn-down building parts, but it could still be considered an energy renovation, because insulation was added to walls, better-than-average windows were chosen, and so on. The measurements and calculations show that the house has achieved an average saving of about DKK 8400 per year. With a total investment for the renovation (disregarding the later investment of upgrading rooms 03 and 04) of DKK 850 000, this would result in a payback time of about 100 years. This figure alone might indicate that this was not a sensible investment, but the increased value of the house, the improved terms for the mortgage, the improved condition of the building parts, and the improved comfort in the house say otherwise. This shows how problematic it can be if there is too much focus on the simple economic and energy savings that can be achieved through renovation.

In this renovation, part of the energy saving was lost due to the rebound effect, where energy is used to achieve a higher comfort level than before the renovation. This is not surprising, as the rebound effect is very common, and well documented in literature, even though the size of it can be difficult to predict, as it depends heavily on user behaviour. Even though the rebound effect makes it more difficult to predict the exact energy saving that can be achieved, it is not necessarily a bad thing to have a rebound effect. In this case, the house owner could save a lot of energy by lowering the temperature a little all over the house. But to have cold rooms, with a temperature below $15{ }^{\circ} \mathrm{C}$, can give problems with drought and moisture, so increasing the temperature in the cold rooms actually help to create a more heathy environment in the house. In this way, the rebound effect is often more a problem for building professionals when making calculations and by reducing the credibility of energy renovation, than it is an actual problem in the house due to behaviour. 
However, it is very important to take into consideration if the budget of a renovation depends on the achieved savings, or when making political goals in this field, as the saving potential might be less than expected.

\section{Conclusion}

This paper has documented the renovation of a typical Danish single-family house and thrown light on the benefits. The house was renovated to improve its durability, decrease energy consumption, and increase indoor climate comfort - all within a feasible budget. Building elements approaching the end of their service life were replaced. The energy consumption of the house was reduced by $23 \%$. The energy consumption needed for heating was reduced by $53 \%$. Measurements in the house show that the temperatures are now less fluctuating and more even throughout the house. The house owners report that the house is now cooler in summer and warmer in winter, and they are no longer bothered by cold draughts. The investment in the renovation totalled DKK 1.3 million, while the increase in the value of the house has been determined to be about DKK 1.2 million (incl. DKK 200000 due to change in price index). Moreover, the house owners will save about DKK 8,400 per year on gas and electricity. Documenting this renovation has shown that, while many projects are unable to match the expectations created by simulations, it really is possible to achieve a relevant renovation that updates the house and reduces energy consumption, while staying within a feasible budget. The study has shown that from the house owners perspective, a general renovation can be successful and economically balanced, while improving the comfort and general condition of the building increasing its functional lifetime. From a researcher/adviser perspective, the study has highlighted the necessity to include the rebound effect when predicting energy savings. Further it is suggested that this should not only be considered a problem, as it is not only increases comfort for the occupants, it can actually be beneficial for the building itself to avoid very cold rooms. On a national level, however, the study suggests that the energy savings that can be achieved through renovating the building stock, might be less than hoped based on general analysis of the potential. This does not suggest that energy savings in the building stock should not be pursued, however, it may be necessary to lower the expectations as to what can be achieved.

\section{Acknowledgements}

This research was supported by the Energy Technology Development and Demonstration Program (EUDP) through the project EUDP 2009-II for the development and demonstration of system solutions for renovating the building envelope of existing single-family houses. We wish to thank all the project partners who participated in this project and contributed with their knowledge. Thanks are also due to the craftsmen and advisors who took part in this project. And special thanks are due to the owners of the house who chose to participate in this project; without their cooperation, it would not have been possible. 


\section{References}

Audenaert, A., Briffaerts, K., and Engels, L. (2011). "Practical versus theoretical domestic energy consumption for space heating." Energy Policy, 39(9), 5219-5227.

Bartiaux, F., Gram-Hanssen, K., Fonseca, P., Ozolina, L., and Christensen, T. H. (2014). “A practicetheory approach to homeowners' energy retrofits in four European areas." Building Research \& Information, 42(June 2015), 525-538.

Bjørneboe, M. G., Svendsen, S., and Heller, A. (2017). “Case study : Using a One-Stop-Shop concept to guide decisions when single-family houses are renovated." Journal of Architectural Engineering, 1-34.

Bromley, M. (2008). “Degree Days - An Introduction." <http://www.degreedays.net/introduction> (Jan. 19, 2017).

Danish Meteorological Institute DMI. "Vejrarkiv." <http://www.dmi.dk/vejr/arkiver/vejrarkiv/> (Oct. 13, 2016).

Danish Meteorological Institute DMI. "Vejrarkiv." <http://www.dmi.dk/vejr/arkiver/vejrarkiv/> (Jun. 20, 2010).

Danish Transport and Construction Agency. (2015). Danish Building Regulations 2015 ( BR15).

Dansk Standard. (2001). DS/EN 13829 Bygningers termiske ydeevne - Bestemmelse af luftgennemtrængelighed i bygninger - Prøuningsmetode med overtryk skabt af ventilator. Dansk Standard, Denmark.

EBC - Energy in Buildings and Communities Programme. (2012). "Annex 58 - Reliable Building Energy Performance Characterisation Based on Full Scale Dynamic Measurements." <http://scholar.google.com/scholar?hl=en\&btnG=Search\&q=intitle:Reliable+building+energy +performance+characterisation+based+on+full+scale+dynamic+measurements\#0> (Nov. 14, 2016).

Energistyrelsen, and Danish Energy Agency. (2016). "Energimærkning af huse [in Danish]." <http://sparenergi.dk/forbruger/vaerktoejer/bedrebolig/raadgiver> (May 12, 2016).

Galvin, R., and Sunikka-Blank, M. (2013). "Economic viability in thermal retrofit policies: Learning from ten years of experience in Germany." Energy Policy, 54, 343-351.

Gram-Hanssen, K. (2014). "Existing buildings - Users, renovations and energy policy." Renewable Energy, Elsevier, 61, 136-140.

Gupta, R., and Gregg, M. (2016). “Do deep low carbon domestic retrofits actually work?" Energy and Buildings, 129, 330-343.

Harrestrup, M., and Svendsen, S. (2015). "Full-scale test of an old heritage multi-storey building undergoing energy retrofitting with focus on internal insulation and moisture." Building and 
Environment, 85, 123-133.

Ma, Z., Cooper, P., Daly, D., and Ledo, L. (2012). "Existing building retrofits: Methodology and stateof-the-art." Energy and Buildings, Elsevier B.V., 55, 889-902.

Majcen, D., Itard, L. C. M., and Visscher, H. (2013). "Theoretical vs. actual energy consumption of labelled dwellings in the Netherlands: Discrepancies and policy implications." Energy Policy, 54, 125-136.

Retsinformation.dk, and Energi-, F. K. (2016). "Bekendtgørelse om energimærkning af bygninger." <https://www.retsinformation.dk/Forms/R0710.aspx?id=183227\#idbee7ebec-6981-48b28d62-5b024a737317> (Oct. 18, 2016).

Risholt, B., Time, B., and Hestnes, A. G. (2013). "Sustainability assessment of nearly zero energy renovation of dwellings based on energy, economy and home quality indicators." Energy and Buildings, Elsevier B.V., 60, 217-224.

SBi Danish Building Research Institute. (2006). "Be10, Building energy requirement software."

SBi Danish Building Research Institute. (2008). SBi-anvisning 213 Bygningers energibehov Beregningsvejledning.

SBi Danish Building Research Institute. (2015). "BSim - The complete program package for building energy design."

Statistics Denmark. (2015). "Income - $\quad$ Statistics Denmark." <https://www.dst.dk/en/Statistik/emner/indkomster> (Jan. 19, 2017).

Statistics Denmark. (2016). "Price index for sales of property ( $2006=100$ ) by category of real property and time." <http://www.statistikbanken.dk/statbank5a/selectvarval/saveselections.asp?MainTable=EJE N5\&PLanguage $=1 \&$ TableStyle $=\&$ Buttons $=\& P X S I d=201611291668181685949$ EJEN5\&IQY $=\& T C$ $=\& \mathrm{ST}=\mathrm{ST} \& \mathrm{rvar} 0=\& \mathrm{rvar} 1=\& \mathrm{rvar} 2=\& \mathrm{rvar} 3=\& \mathrm{rvar} 4=\& \mathrm{rvar} 5=\& \mathrm{rvar} 6=\& \mathrm{rvar} 7=\& \mathrm{rvar} 8=\& \mathrm{rvar} 9=\& \mathrm{r}$ $\operatorname{var} 10=\& \operatorname{rvar} 11=>$ (Nov. 29, 2016).

Teknologisk Institut. (2007). "Tæthed - god energirådgivning." (september).

Teknologisk Institut. (2015). “Graddage." <http://www.teknologisk.dk/graddage> (Mar. 1, 2015).

Thomsen, K. E., Rose, J., Mørck, O., Jensen, S. Ø., Østergaard, I., Knudsen, H. N., and Bergsøe, N. C. (2016). "Energy consumption and indoor climate in a residential building before and after comprehensive energy retrofitting." Energy and Buildings, Elsevier B.V., 123, 8-16.

Tommerup, H. (2008). "Measurement results and experiences from an energy renovation of a typical Danish single-family house." 8th Symposium on Building Physics in Nordic ..., 1-8.

Tommerup, H., and Svendsen, S. (2006). "Energy savings in Danish residential building stock." Energy and Buildings, 38(6), 618-626. 
træfælderen.dk. (2011). “Brænde." <http://www.traefaelderen.dk/braende> (Mar. 1, 2015).

Vanhoutteghem, L., and Svendsen, S. (2014). "Modern insulation requirements change the rules of architectural design in low-energy homes." Renewable Energy, 72, 301-310.

Vanhoutteghem, L., Tommerup, H. M., Svendsen, S., Mahapatra, K., Gustavsson, L., Haavik, T., Aabrekk, S., Paiho, S., and Ala-juusela, M. (2009). Analysis of promising sustainable renovation concepts.

Wilson, C., Crane, L., and Chryssochoidis, G. (2015). "Why do homeowners renovate energy efficiently? Contrasting perspectives and implications for policy." Energy Research \& Social Science, Elsevier Ltd, 7, 12-22. 